\title{
Phase change behaviour of latent heat storage media based on calcium chloride hexahydrate composites containing strontium
}

\section{chloride hexahydrate and oxidation expandable graphite}

\author{
Xiang $\operatorname{Li}^{\text {a, b, c, } * \text {, Yuan Zhou }}{ }^{\text {a, c, } * \text {, Hongen Nian }}{ }^{\text {a, b, c }}$, Xiufeng Ren ${ }^{\text {a, b, c }}$, \\ Ouyang Dong ${ }^{\text {a,c }}$, Chunxi Hai ${ }^{\text {a,c }}$, Yue Shen ${ }^{\text {a,c }}$, Jinbo Zeng ${ }^{\text {a, c }}$ \\ ${ }^{a}$ Qinghai Institute of Salt Lakes, Chinese Academy of Sciences, Xining, 810008, China, \\ ${ }^{\mathrm{b}}$ University of Chinese Academy of Sciences, Beijing, 100049, China,
}

${ }^{c}$ Key Laboratory of Salt Lake Resources Chemistry of Qinghai Province, Xining, 810008, China

\begin{abstract}
:
Calcium chloride hexahydrate $\left(\mathrm{CaCl}_{2} \cdot 6 \mathrm{H}_{2} \mathrm{O}\right)$ composites PCMs containing strontium chloride hexahydrate $\left(\mathrm{SrCl}_{2} \cdot 6 \mathrm{H}_{2} \mathrm{O}\right)$ and oxidation expandable graphite(EGO) were prepared and phase change behavior of $\mathrm{CaCl}_{2} \cdot 6 \mathrm{H}_{2} \mathrm{O} / \mathrm{EGO} / \mathrm{SrCl}_{2} \cdot 6 \mathrm{H}_{2} \mathrm{O}$ composite $\mathrm{PCMs}$, including supercooling degree, phase change temperature, latent heat, density, thermal conductivity and thermal stability were systematically studied. Results demonstrate that thermal conductivity, heat transfer and the latent capacities of the $\mathrm{CaCl}_{2} \cdot 6 \mathrm{H}_{2} \mathrm{O} / \mathrm{SrCl}_{2} \cdot 6 \mathrm{H}_{2} \mathrm{O} / \mathrm{EGO}$ composite PCMs are significantly enhanced, supercooling of $\mathrm{CaCl}_{2} \cdot 6 \mathrm{H}_{2} \mathrm{O} / \mathrm{SrCl}_{2} \cdot 6 \mathrm{H}_{2} \mathrm{O} / \mathrm{EGO}$ composite PCMs are suppressed, mainly ascribe to that the EGO are homogenously dispersed in PCMs due to the existence of oxygen-containing functional groups in EGO, meanwhile, the well-dispersed EGO serving as nuclei to promote the heterogeneous nucleation and crystallization process of $\mathrm{CaCl}_{2} \cdot 6 \mathrm{H}_{2} \mathrm{O}$. Moreover, a fifty-run-cycling test verifies that the $\mathrm{CaCl}_{2} \cdot 6 \mathrm{H}_{2} \mathrm{O} / \mathrm{SrCl}_{2} \cdot 6 \mathrm{H}_{2} \mathrm{O} / \mathrm{EGO}$ composites PCMs contained with $3 \mathrm{wt} . \% \mathrm{SrCl}_{2} \cdot 6 \mathrm{H}_{2} \mathrm{O}$, and $1.0 \mathrm{wt} . \%$ EGO possesses enhanced thermal behavior with no phase segregation observed; the latent heat was calculated to be $172.26 \mathrm{~J} / \mathrm{g}$.
\end{abstract}

Keywords: Phase change material (PCM); Oxidation expandable graphite (EGO); $\mathrm{CaCl}_{2} \cdot 6 \mathrm{H}_{2} \mathrm{O} / \mathrm{SrCl}_{2} \cdot 6 \mathrm{H}_{2} \mathrm{O} / \mathrm{EGO}$ composites; Phase change behavior

\section{Introduction}

Phase change materials (PCMs) offer an effective route for the efficient usage of latent thermal energy. PCMs are commonly adopted for thermal energy storage field applications e capability of operating under low/medium temperatures and unstable energy storage fields, such as solar energy, industrial waste heat, intermittent electric heating energy, ect [1-4]. The study and development of PCMs that demonstrate high

\footnotetext{
* Corresponding author. Address: Qinghai Institute of Salt Lakes, Chinese Academy of Sciences, Xining 810008, China.

Tel.: +86971 6338403; fax: +869716338403.

E-mail address: lixiang@isl.ac.cn (X. Li), zhouy@isl.ac.cn (Y. Zhou).
} 
performance is of great significance in developing more efficient routes of energy storage, supply, and demand. In the past few decades, PCMs have attracted great attention that sparked numerous investigations from research groups [5-6]. The majority of the PCMs investigated by researchers are classified as organic PCMs, such as paraffin wax and non-paraffin organic compounds [7-11]; meanwhile, inorganic PCMs have received relatively little attention.

The inorganic PCMs, like salt hydrates, have the advantages of higher heat storage capacity, constant phase transition temperature, nonflammable and so on. Thus, it will be more suitable and safer than organic PCMs in energy storage application. For inorganic PCMs, most researchers have studied the calcium chloride hexahydrate $\left(\mathrm{CaCl}_{2} \cdot 6 \mathrm{H}_{2} \mathrm{O}\right) \mathrm{PCM}$ system result from their low cost, easy availability and high thermal storage performance [11-17]. Bilen et al [14], Lane et al [15], Paris et al [16], Liu et al [17] and Duan et al[13] studied the modification of $\mathrm{CaCl}_{2} \cdot 6 \mathrm{H}_{2} \mathrm{O}$ PCM system, and selected different nucleating agents. Bilen et al [14] added 3wt $\%$ $\mathrm{KNO}_{3}$ into $\mathrm{CaCl}_{2} \cdot 6 \mathrm{H}_{2} \mathrm{O}$ PCM system as nucleating agent to prevent supercooling in the melting and solidification process, which showed obvious performance improvement. Lane et al [15] reported strontium chloride $\left(\mathrm{SrCl}_{2} \cdot 6 \mathrm{H}_{2} \mathrm{O}\right)$ can be employed as nucleating agent in $\mathrm{CaCl}_{2} \cdot 6 \mathrm{H}_{2} \mathrm{O} \mathrm{PCM}$ system, $\mathrm{SrCl}_{2} \cdot 6 \mathrm{H}_{2} \mathrm{O}$ can suppress the supercooling. Paris et al [16] made the comparison of $\mathrm{Ba}(\mathrm{OH})_{2} \cdot 8 \mathrm{H}_{2} \mathrm{O}$ and $\mathrm{SrCl}_{2} \cdot 6 \mathrm{H}_{2} \mathrm{O}$ as nucleating agents, and the results indicated that the mixtures of $\mathrm{CaCl}_{2} \cdot 6 \mathrm{H}_{2} \mathrm{O}$ with $3 \mathrm{wt} \% \quad \mathrm{SrCl}_{2} \cdot 6 \mathrm{H}_{2} \mathrm{O}$ exhibited stable thermal behavior than $\mathrm{Ba}(\mathrm{OH})_{2} \cdot 8 \mathrm{H}_{2} \mathrm{O}$. And Liu et al [17] investigated the thermal properties of $\mathrm{CaCl}_{2} \cdot 6 \mathrm{H}_{2} \mathrm{O}$ PCM system with several nucleating agents, and the results suggested that $\mathrm{SrCl}_{2} \cdot 6 \mathrm{H}_{2} \mathrm{O}$ and borax can prevent the supercooling. Nevertheless, strontium chloride behaving individually is not effective at eliminating supercooling,

Recently, expandable graphite (EG) has play an important role in energy storage which attracted much attention because of its light weight, high thermal energy storage ability by high expansion volume (exhibiting a layered and porous structure) $[13,18]$. Duan et al. [13] investigated the influence of the expandable graphite on the supercooling and phase separation behavior of $\mathrm{CaCl}_{2} \cdot 6 \mathrm{H}_{2} \mathrm{O}$ and the results indicated that EG can effectively increase the thermal conductivity and promote phase change performance. However, owing to the existence of nonpolar function groups on the EG surface, a negligible surface tension and size effect aggravate the hydrophillic performance of EG. It leads to uniform distribution of EG in the organic PCM, which would cause the cyclic performance of the inorganic PCM deteriorate over elapsed time. Therefore, the practical applications of $\mathrm{CaCl}_{2} \cdot 6 \mathrm{H}_{2} \mathrm{O}$ PCM system in energy conservation still needs more research about supercooling, thermal conductivity and the loss for the latent heat storage.

Besides the advantages of light weight, high thermal energy storage ability by high expansion volume (exhibiting a layered and porous structure), oxidation expandable graphite (EGO) surface contains an abundant amount of oxygen-containing functional groups; the existence of the oxygen-containing polar functional groups helps facilitates an even distribution of EGO throughout the inorganic PCM. Meanwhile, the cation and anion of the inorganic PCM are easily 
adsorbed by said polar functional groups. Due to the decreased diffusion capacity of particles in the PCM solution, the contact probability of particle nucleation effectively increases in this composite. However, there is very little data regarding the research about $\mathrm{CaCl}_{2} \cdot 6 \mathrm{H}_{2} \mathrm{O} / \mathrm{SrCl}_{2} \cdot 6 \mathrm{H}_{2} \mathrm{O} / \mathrm{EGO}$ composites.

Herein, we prepared $\mathrm{CaCl}_{2} \cdot 6 \mathrm{H}_{2} \mathrm{O} / \mathrm{SrCl}_{2} \cdot 6 \mathrm{H}_{2} \mathrm{O} / \mathrm{EGO}$ composites PCMs and phase change behavior of $\mathrm{CaCl}_{2} \cdot 6 \mathrm{H}_{2} \mathrm{O} / \mathrm{SrCl}_{2} \cdot 6 \mathrm{H}_{2} \mathrm{O} / \mathrm{EGO}$ composites PCMs, including supercooling degree, phase change temperature, latent heat, density, thermal conductivity and thermal stability were systematically studied. The objective of this work is to explore the more efficient mechanism that optimizes the thermal properties of the hydrated salts for successful commercialization in thermal energy storage systems.

\section{Experimental works}

\subsection{Materials}

Anhydrous calcium chloride $\left(\mathrm{CaCl}_{2}\right.$, purity $>96 \%$, Tianjin Yongda chemical Co., Ltd.), strontium chloride hexahydrate $\left(\mathrm{SrCl}_{2} \cdot 6 \mathrm{H}_{2} \mathrm{O}\right.$, purity $>99 \%$, Tianjin Yongda chemical Co., Ltd.) and were used as purchased, natural graphite in particle form (with an average diameter of $500 \mathrm{~mm}$ ) was purchased from Tianjin Yongda chemical Co., Ltd.. Sodium dodecyl benzene sulfonate (SDBS) was purchased from Sigma Aldrich Co..

\subsection{Preparation of $\mathrm{CaCl}_{2} \cdot \mathbf{6 H}_{2} \mathrm{O}$ and EGO}

The material $\mathrm{CaCl}_{2} \cdot 6 \mathrm{H}_{2} \mathrm{O}$ was prepared via dissolution and crystallization of industrial grade $\mathrm{CaCl}_{2}$.

The oxidation expandable graphite was prepared through the following procedure: the natural graphite flakes was dried in a vacuum oven at $80{ }^{\circ} \mathrm{C}$ for $15 \mathrm{~h}$. Then, it was heated in a microwave oven at a power of $1,500 \mathrm{~W}$ for $15-20 \mathrm{~s}$. The EG was obtained after the microwave treatment. The EGO was prepared based on the conventional Hummer's method of oxidation [19].

\subsection{Preparation of $\mathrm{CaCl}_{2} \cdot \mathbf{6} \mathrm{H}_{2} \mathrm{O} / \mathrm{SrCl}_{2} \cdot \mathbf{6} \mathrm{H}_{2} \mathrm{O} / \mathrm{EGO}$ composites}

$\mathrm{CaCl}_{2} \cdot 6 \mathrm{H}_{2} \mathrm{O}$ was melted at approximately $60^{\circ} \mathrm{C}$. Consequently, SDBS was added into the melted mixture to form a stable emulsion by ultrasonic dispersion for $30 \mathrm{~min}$. Subsequently, $\mathrm{SrCl}_{2} \cdot 6 \mathrm{H}_{2} \mathrm{O}$ and EGO were added into the emulsion and the mixture; the resulting mixture was then stirred for $30 \mathrm{~min}$. Finally, the $\mathrm{CaCl}_{2} \cdot 6 \mathrm{H}_{2} \mathrm{O}$ composite containing $\mathrm{SrCl}_{2} \cdot 6 \mathrm{H}_{2} \mathrm{O}$ and EGO was synthesized. The compositions of the various $\mathrm{CaCl}_{2} \cdot 6 \mathrm{H}_{2} \mathrm{O}$ composites are listed in Table 1 .

\section{Table 1}

\subsection{Characterization}

The solid-state thermal conductivity values for $\mathrm{CaCl}_{2} \cdot 6 \mathrm{H}_{2} \mathrm{O} / \mathrm{SrCl}_{2} \cdot 6 \mathrm{H}_{2} \mathrm{O} / \mathrm{EGO}$ 
composites could be measured by the thermal equilibrium method using ASTM D5470.The analysis of EGO was carried out via FTIR spectroscopy (Nexus). Differential scanning calorimetry (DSC) was conducted at a heating rate of $1{ }^{\circ} \mathrm{C} \mathrm{min}^{-1}$ under a constant stream of argon at atmospheric pressure using a NETZSCH DSC 200 F3. The temperature precision of the DSC is $0.1{ }^{\circ} \mathrm{C}$, the calorimetric precision of the DSC is $1 \%$. The crystallization processes of pure $\mathrm{CaCl}_{2} \cdot 6 \mathrm{H}_{2} \mathrm{O}$ and $\mathrm{CaCl}_{2} \cdot 6 \mathrm{H}_{2} \mathrm{O}$ composite samples were observed and recorded under an optical microscope with a CCD camera (Axioskop 40 Pol, Zeiss). Photographs showing the dispersion stability in water were recorded using a digital camera (CASIO EX-TR550).

The values of supercooling and heat storage curves were tested as following procedure: fifty-gram of sample was weighted and placed in a test tube $(30 \mathrm{~mm}$ in diameter and $100 \mathrm{~mm}$ in high), and the thermocouple of temperature recorder (with a maximum error of $0.1^{\circ} \mathrm{C}$ ) was inserted into the center of the test tube, which was then put in the thermostat (with temperature stability of $0.5^{\circ} \mathrm{C}$.) at a constant temperature of $60^{\circ} \mathrm{C}$ and when the temperature of sample reached to $55^{\circ} \mathrm{C}$, the test tubes were transferred to a $10{ }^{\circ} \mathrm{C}$ thermostatic water bath. Finally, the values of supercooling were recorded by a computer controlled data acquisition system with an interval data recordation time of $60 \mathrm{~s}$. To obtain the heat storage curves, the test tubes with PCMs were put into a $10^{\circ} \mathrm{C}$ thermostatic water bath, and when the temperature of sample reached to $15^{\circ} \mathrm{C}$, the test tubes were transferred to a $60{ }^{\circ} \mathrm{C}$ thermostatic water bath.

\section{Results and discussion}

\subsection{Supercooling of $\mathrm{CaCl}_{2} \cdot \mathbf{6} \mathrm{H}_{2} \mathrm{O} / \mathrm{SrCl}_{2} \cdot \mathbf{6} \mathrm{H}_{2} \mathrm{O} / \mathrm{EGO}$ composites $\mathrm{PCMs}$}

Fig. 1 illustrates the relationship between $\mathrm{SrCl}_{2} \cdot 6 \mathrm{H}_{2} \mathrm{O}$ concentration and the degree supercooling of $\mathrm{CaCl}_{2} \cdot 6 \mathrm{H}_{2} \mathrm{O}$. The supercooling degree of the $\mathrm{CaCl}_{2} \cdot 6 \mathrm{H}_{2} \mathrm{O} \mathrm{PCM}$ after adding increasing mass fractions $(1.0 \%, 2.0 \%, 3.0 \%, 4.0 \%$ and $5.0 \%)$ of $\mathrm{SrCl}_{2} \cdot 6 \mathrm{H}_{2} \mathrm{O}$ were $13.8,9,6.6,2.8,3.9$ and $4.1^{\circ} \mathrm{C}$, respectively. As the concentration of $\mathrm{SrCl}_{2} \cdot 6 \mathrm{H}_{2} \mathrm{O}$ increases, the supercooling degree of the $\mathrm{CaCl}_{2} \cdot 6 \mathrm{H}_{2} \mathrm{O}$ PCM decreases until the content of $\mathrm{SrCl}_{2} \cdot 6 \mathrm{H}_{2} \mathrm{O}$ reaches $3 \%$ (on mass basis) where the supercooling degree begins to increase; therefore, $3 \% \mathrm{SrCl}_{2} \cdot 6 \mathrm{H}_{2} \mathrm{O}$ content is effectively the ideal concentration for the most optimum effect to reduce the supercooling phenomenon.

Fig.1

Fig. 2 displays the crystal structure of $\mathrm{CaCl}_{2} \cdot 6 \mathrm{H}_{2} \mathrm{O}$ and $\mathrm{CaCl}_{2} \cdot 6 \mathrm{H}_{2} \mathrm{O}$ with 3 wt $\%$ $\mathrm{SrCl}_{2} \cdot 6 \mathrm{H}_{2} \mathrm{O}$, recorded during the crystallization process. Fig. 2 (b, c, d) is the photo of the crystal of $\mathrm{CaCl}_{2} \cdot 6 \mathrm{H}_{2} \mathrm{O}$ with $3 \mathrm{wt} \% \mathrm{SrCl}_{2} \cdot 6 \mathrm{H}_{2} \mathrm{O}$. It should be indicated that the black spots in the Fig.2 (b, c) are nucleating agent. In comparison with pure $\mathrm{CaCl}_{2} \cdot 6 \mathrm{H}_{2} \mathrm{O}$, the crystal size of $\mathrm{CaCl}_{2} \cdot 6 \mathrm{H}_{2} \mathrm{O}$ with $3 \mathrm{wt} \% \mathrm{SrCl}_{2} \cdot 6 \mathrm{H}_{2} \mathrm{O}$ appears much smaller in size, facilitating the prevention of phase segregation. Furthermore, It is clear that the pure $\mathrm{CaCl}_{2} \cdot 6 \mathrm{H}_{2} \mathrm{O}$ (Fig. 2(a)) sans $\mathrm{SrCl}_{2} \cdot 6 \mathrm{H}_{2} \mathrm{O}$ behaving as a nucleating agent gradually produced needle-like crystals whereas the $\mathrm{CaCl}_{2} \cdot 6 \mathrm{H}_{2} \mathrm{O}$ composites $\left(\mathrm{N}_{3}\right)$ containing $\mathrm{SrCl}_{2} \cdot 6 \mathrm{H}_{2} \mathrm{O}$ (b, c, d) rapidly formed small grain-like crystals near the 
$\mathrm{SrCl}_{2} \cdot 6 \mathrm{H}_{2} \mathrm{O}$ phase. Moreover, adding nucleating agent can effectively improve the crystalline state of the PCMs. In accordance with crystallization theory, too few nucleating agents cause a negligible number of nuclei exhibiting a hindered nucleation effect. Once the content of nucleating agents reaches a threshold amount (typically more than 3\%), their effect becomes ineffective and typically destructive for the nucleation process. This behavior can be explained by the high concentration of impurities that decrease the calcium and chloride ion mobility, creating a difficult environment for diffusion of ions to the nuclease that prevents crystallization. Fig. 1 illustrates the supercooling phenomenon that exists in samples $\mathrm{N}_{1}-\mathrm{N}_{5}$ despite the addition of $\mathrm{SrCl}_{2} \cdot 6 \mathrm{H}_{2} \mathrm{O}$ as a nucleating agent.

Fig.2

In order to completely remove and/or minimize the supercooling behavior, the second segment of the investigation was conducted with the addition of a variable weight percentage of EGO in various samples. The FTIR spectra of the EGO is presented in Fig. 3 that displays EGO's characteristic bands at 1622, 1421, and 1018 $\mathrm{cm}^{-1}$ assigned to $\mathrm{O}-\mathrm{H}$ stretching, $\mathrm{C}-\mathrm{OH}$ stretching, and $\mathrm{C}-\mathrm{O}$ stretching, respectively. Moreover, an obvious peak at $3423 \mathrm{~cm}^{-1}$ can be observed in the spectrum that is mainly attributed to the hydroxyl stretching vibrations of water. It can be concluded that the EGO surface contains excessive amounts of oxygen-containing functional groups, which is advantageous for dispersion stability. Meanwhile, the cation and anion of the inorganic PCM are easily adsorbed onto the surface due to said polar functional groups. As a result of the weakened diffusion capacity of particles in the calcium chloride solution, the contact probability of particle nucleation effectively increases due to the EGO additive. Fig. 4 presents the structure diagram of EGO.

Fig.3

Fig. 4

Fig. 5 presents the digital photos of the dispersion stability of EG and EGO in water. The EG completely precipitate after $1 \mathrm{~h}$ (Fig. 5a). In comparison, EGO show no precipitation after sedimentation for $48 \mathrm{~h}$ (Fig. 5b), indicating the significant improved dispersion stability of EGO in water which is advantageous for phase change performance. It can be explained as follows. EGO surface contains excessive amounts of oxygen-containing functional groups, which results in the good compatibility between EGO and water according to the theory of "similarity and intermiscibility".

Fig. 5

Fig. 6 shows cooling curves of the $\mathrm{CaCl}_{2} \cdot 6 \mathrm{H}_{2} \mathrm{O} / \mathrm{SrCl}_{2} \cdot 6 \mathrm{H}_{2} \mathrm{O} / \mathrm{EGO}$ composites PCMs with different EGO contents. Results indicate that the supercooling degree of 
samples $\left(\mathrm{N}_{3-2}, \mathrm{~N}_{3-4}, \mathrm{~N}_{3-6}, \mathrm{~N}_{3-8}, \mathrm{~N}_{3-10}\right)$ are $1.0,0.3,0.7,0.9$ and $0.6^{\circ} \mathrm{C}$, respectively. The phase change temperature range was between $28^{\circ} \mathrm{C}$ and $29^{\circ} \mathrm{C}$ and the exothermic lasting time is more than $100 \mathrm{~min}$. When further increasing the amount of EGO to 1.2 wt $\%$ ( samples $\mathrm{N}_{3-12}$ ), the supercooling degree increase to $3.4^{\circ} \mathrm{C}$. It is ascribed that the introduction of EGO suppresses the supercooling, and the main reasons can be explained by EGO as nucleation agent. Without adding EGO, the crystallization process of $\mathrm{CaCl}_{2} \cdot 6 \mathrm{H}_{2} \mathrm{O} / \mathrm{SrCl}_{2} \cdot 6 \mathrm{H}_{2} \mathrm{O}$ is sluggish to some extent, leading to supercooling phenomenon. The well dispersed EGO which provide stable foreign nuclei to promote the heterogeneous nucleation and accelerate crystallization process. However, too much EGO restrain the crystallization growth of $\mathrm{CaCl}_{2} \cdot 6 \mathrm{H}_{2} \mathrm{O}$ and reduce the ratio of phase change component $\mathrm{CaCl}_{2} \cdot 6 \mathrm{H}_{2} \mathrm{O}$ in the composite. In consideration of dispersion stability, and supercooling degree, $1.0 \%$ was the maximum concentration of EGO in $\mathrm{CaCl}_{2} \cdot 6 \mathrm{H}_{2} \mathrm{O} / \mathrm{SrCl}_{2} \cdot 6 \mathrm{H}_{2} \mathrm{O} / \mathrm{EGO}$ composites PCMs.

Fig. 6

\subsection{Thermal conductivity of $\mathrm{CaCl}_{2} \cdot 6 \mathrm{H}_{2} \mathrm{O} / \mathrm{SrCl}_{2} \cdot 6 \mathrm{H}_{2} \mathrm{O} / \mathrm{EGO}$ composites $\mathrm{PCMs}$}

Thermal conductivity is the primary mechanism to gauge the rate of heat storage and release during fusing and crystallizing processes. Low thermal conductivity not only signifies a reduction in the heat storage and release, while also restricting its application. As shown in Fig. 7, the thermal conductivities of the $\mathrm{CaCl}_{2} \cdot 6 \mathrm{H}_{2} \mathrm{O}$ composites $\left(\mathrm{N}_{3-2}, \mathrm{~N}_{3-4}, \mathrm{~N}_{3-6}, \mathrm{~N}_{3-8}\right.$, and $\left.\mathrm{N}_{3-10}\right)$ PCMs are relatively higher than the sample $\mathrm{N}_{3}(0.341 \mathrm{~W} / \mathrm{m} \cdot \mathrm{K})$. Additionally, it was determined that the thermal conductivity of the $\mathrm{CaCl}_{2} \cdot 6 \mathrm{H}_{2} \mathrm{O} / \mathrm{SrCl}_{2} \cdot 6 \mathrm{H}_{2} \mathrm{O} / \mathrm{EGO}\left(\mathrm{N}_{3-2}, \mathrm{~N}_{3-4}, \mathrm{~N}_{3-6}, \mathrm{~N}_{3-8}\right.$, and $\left.\mathrm{N}_{3-10}\right)$ demonstrate a marked increase as the amount of EGO in the composites increased, indicative of the primary contribution for achieving high thermal conductivity is due to the thermal behavior of and the specific expansion of the EGO structure. The above figures explain that the thermal conductivities of samples $\left(\mathrm{N}_{3-2}, \mathrm{~N}_{3-4}, \mathrm{~N}_{3-6}, \mathrm{~N}_{3-8}\right.$, and $\mathrm{N}_{3-10}$ ) are in the range of $0.693-1.832 \mathrm{~W} / \mathrm{m} \cdot \mathrm{K}$; simultaneously, data fitting curves are also displayed in the figure. Results reveal that the rule of the data variability aligns with the formula as follows: $Y=0.03356 X^{3}-0.21419 X^{2}+1.67066 X+0.3473$. The $R^{2}$ parameter is implemented to express the correlation between this formula and the rule of experimental data changes. After calculation, it is obtained that $R^{2}=0.9899$ and is very close to 1 (signifying a $100 \%$ fit). Therefore, the correlation of the experimental data and the fitting curve is excellent. The addition of EGO is not only beneficial in the reduction of the degree of supercooling, but also facilitates an enhancement of thermal conductivity.

\section{Fig. 7}

Fig. 8 shows the heat storage curves of $\mathrm{CaCl}_{2} \cdot 6 \mathrm{H}_{2} \mathrm{O} / \mathrm{SrCl}_{2} \cdot 6 \mathrm{H}_{2} \mathrm{O}$ and $\mathrm{CaCl}_{2} \cdot 6 \mathrm{H}_{2} \mathrm{O} / \mathrm{SrCl}_{2} \cdot 6 \mathrm{H}_{2} \mathrm{O} / \mathrm{EGO} /$ composites PCMs. As can be seen from the heat storage curve, it takes $380 \mathrm{~min}$ for $\mathrm{CaCl}_{2} \cdot 6 \mathrm{H}_{2} \mathrm{O} / \mathrm{SrCl}_{2} \cdot 6 \mathrm{H}_{2} \mathrm{O}$ to increase the equilibrium temperature from $15^{\circ} \mathrm{C}$ to $50^{\circ} \mathrm{C}$. Besides, the temperature rises rather 
slow with quite a long heat storage platform at $c a .29^{\circ} \mathrm{C}$. When adding $0.2,0.4,0.6$, $0.8,1.0 \mathrm{wt} \% \mathrm{EGO}$, the time taken for the temperature from $15^{\circ} \mathrm{C}$ to $50^{\circ} \mathrm{C}$ is reduced to $240,157,131,110$, and $96 \mathrm{~min}$, showing improved heat transfer rate of the composites. This is attributed to the fact that the addition of EGO improves the thermal conductivity of the composite PCMs, facilitating the heat transfer in the heat storage process. Thus, the heat storage time to get equilibrium temperature is reduced for $\mathrm{CaCl}_{2} \cdot 6 \mathrm{H}_{2} \mathrm{O} / \mathrm{SrCl}_{2} \cdot 6 \mathrm{H}_{2} \mathrm{O} / \mathrm{EGO} /$ composites PCMs.

\section{Fig. 8}

\subsection{The latent heat of $\mathrm{CaCl}_{2} \cdot 6 \mathrm{H}_{2} \mathrm{O} / \mathrm{SrCl}_{2} \cdot 6 \mathrm{H}_{2} \mathrm{O} / \mathrm{EGO}$ composites $\mathrm{PCMs}$}

Fig. 9 illustrates the DSC curves of the measured samples $\left(\mathrm{N}_{3}, \mathrm{~N}_{3-2}, \mathrm{~N}_{3-4}, \mathrm{~N}_{3-6}\right.$, $\mathrm{N}_{3-8}$, and $\mathrm{N}_{3-10}$ ). It is noticed that the latent heat capacity of $\mathrm{CaCl}_{2} \cdot 6 \mathrm{H}_{2} \mathrm{O} / \mathrm{SrCl}_{2} \cdot 6 \mathrm{H}_{2} \mathrm{O}$ is $158.97 \mathrm{~J} / \mathrm{g}$, while the latent capacities of the composites PCMs with 0.2, 0.4, 0.6, 0.8 and $1.0 \mathrm{wt} \%$ EGO increase to $161.42 \mathrm{~J} / \mathrm{g}, 163.81,166.54,169.47 \mathrm{~J} / \mathrm{g}$ and 174.51 $\mathrm{J} / \mathrm{g}$, respectively. The enhancement of the latent capacities of the composites can be explained by EGO as heterogeneous nucleation agent, which is advantageous for the crystallization growth of $\mathrm{CaCl}_{2} \cdot 6 \mathrm{H}_{2} \mathrm{O}$.

\section{Fig. 9}

\subsection{Thermal cycling stability}

The $\mathrm{CaCl}_{2} \cdot 6 \mathrm{H}_{2} \mathrm{O} / \mathrm{SrCl}_{2} \cdot 6 \mathrm{H}_{2} \mathrm{O} / \mathrm{EGO} /$ composites $\mathrm{PCMs}$ are required to maintain thermal stability during a substantial number of melting and freezing cycles; therefore, a thermal cycling test is employed to deduce thermal reliability of PCM composites from the viewpoint of the supercooling, segregation and latent heat changes throughout the thermal cycling measurement. The apparatus for these experiments consisted of the test tubes containing a representative sample $\left(\mathrm{N}_{3-10}\right)$ that was placed into the temperature-controlled water bath. The selected heating and cooling temperatures are $60.0^{\circ} \mathrm{C}$ and $10^{\circ} \mathrm{C}$, respectively, and the results of the cyclic performance tests of sample $\left(\mathrm{N}_{3-10}\right)$ are presented in Fig.10. It can be seen from Fig.10 that the sample $\left(\mathrm{N}_{3-10}\right)$ maintains adequate thermal stability up to 50 cycles: the variation of the phase change temperature is within the range $27.6-29.6{ }^{\circ} \mathrm{C}$, and the degree of supercooling is within the range of $0-1.4{ }^{\circ} \mathrm{C}$. The phase change temperature and latent heat were also measured by DSC as shown in Fig. 11. The latent heat was calculated to be $172.26 \mathrm{~J} / \mathrm{g}$. These results were attributed to the worm-like pore structures caused by the expansion of the EGO Ref. [20]. The increased viscosity caused by the 1wt\% SDBS widened the surface contact of EGO and also prevented phase segregation by uniformly dispersing the EGO within the molten $\mathrm{CaCl}_{2} \cdot 6 \mathrm{H}_{2} \mathrm{O}$ during the thermal cycling tests. 


\section{Fig. 11}

\subsection{Density Analysis}

Due to the slight volume change of the $\mathrm{CaCl}_{2} \cdot 6 \mathrm{H}_{2} \mathrm{O} / \mathrm{SrCl}_{2} \cdot 6 \mathrm{H}_{2} \mathrm{O} / \mathrm{EGO}$ / composites PCMs $\left(\mathrm{N}_{3-10}\right)$ from solid to liquid, the density of the sample $\left(\mathrm{N}_{3-10}\right)$ was measured at room temperature to be a value of $1.43 \times 10^{3} \mathrm{~kg} / \mathrm{m}^{3}$. Subsequently, the latent heat of the sample is $2.46 \times 10^{5} \mathrm{~kJ} / \mathrm{m}^{3}$, which verifies the feasibility of this material as a PCMs with a large latent heat for building energy-saving applications.

\subsection{Simulation experiments}

In simulation experiments, the quality of the phase change material was calculated by the thermal compensation requirement as shown below:

$$
C_{0} \times M_{0} \times \Delta T=\Delta H \times m
$$

where $C_{0}$ is the specific heat of water, $\Delta T$ is the water temperature difference, $M_{0}$ is the quality of water, $m$ is the quality of phase change material, and $\Delta H$ is the latent heat of phase change material. In simulation experiments, the quality of water is about $2 \mathrm{Kg}$, the initial temperature of water was $50{ }^{\circ} \mathrm{C}$, and the water temperature difference was about $25^{\circ} \mathrm{C}$. Fig. 11 depicts the illustration for the simulation experiment.

\section{Fig. 12}

Fig.12 illustrates the temperature change of water in a heat storage tank. As can observed in the plot, the temperature of water in the heat storage tank without PCMs rapidly decreases as a function of elapsed time while at the identical cooling condition, which then steadily plateaus at room temperature after $400 \mathrm{~min}$. When the heat storage tank contains $\mathrm{CaCl}_{2} \cdot 6 \mathrm{H}_{2} \mathrm{O} / \mathrm{SrCl}_{2} \cdot 6 \mathrm{H}_{2} \mathrm{O} / \mathrm{EGO} /$ composites $\mathrm{PCMs}\left(\right.$ sample $\mathrm{N}_{3-10}$ ), once the temperature reaches the PCM's phase change temperature after $400 \mathrm{~min}$, the phase transition occurs and the temperature of water remains relatively constant until the completion of the phase change, then the temperature of water begins to decrease as expected. Thus, $\mathrm{CaCl}_{2} \cdot 6 \mathrm{H}_{2} \mathrm{O} / \mathrm{SrCl}_{2} \cdot 6 \mathrm{H}_{2} \mathrm{O} / \mathrm{EGO} /$ composites PCMs (sample $\mathrm{N}_{3-10}$ ) applied in the storage tanks could improve the capability of heat accumulation, exothermicity and the time of releasing heat. The results establish the material's feasibility for heating system of solar heat collection device coupling phase change materials.

\section{Fig. 13}

\section{Conclusions}


$\mathrm{CaCl}_{2} \cdot 6 \mathrm{H}_{2} \mathrm{O} / \mathrm{SrCl}_{2} \cdot 6 \mathrm{H}_{2} \mathrm{O} / \mathrm{EGO} /$ composites PCMs were prepared and demonstrated excellent phase change behavior including supercooling degree, phase change temperature, latent heat, thermal conductivity and thermal stability which were attributed to that the EGO are homogenously dispersed in PCMs due to the existence of oxygen-containing functional groups in EGO, meanwhile, the well-dispersed EGO serving as nuclei to promote the heterogeneous nucleation and crystallization process of $\mathrm{CaCl}_{2} \cdot 6 \mathrm{H}_{2} \mathrm{O}$. The thermal conductivity of the $\mathrm{CaCl}_{2} \cdot 6 \mathrm{H}_{2} \mathrm{O} / \mathrm{SrCl}_{2} \cdot 6 \mathrm{H}_{2} \mathrm{O} / \mathrm{EGO} /$ composites PCMs increases with increasing EGO content. With 1.0wt\% EGO, the thermal conductivity of composite PCMs increases to $1.832 \mathrm{~W} / \mathrm{m} \cdot \mathrm{K}$. It is also encouraging that the EGO have significant effect in reducing supercooling. With $1.0 \mathrm{wt} \% \mathrm{EGO}$, the supercooling degree is practically negligible $\left(<1^{\circ} \mathrm{C}\right)$. Moreover, the $\mathrm{CaCl}_{2} \cdot 6 \mathrm{H}_{2} \mathrm{O} / \mathrm{SrCl}_{2} \cdot 6 \mathrm{H}_{2} \mathrm{O} / \mathrm{EGO} /$ composites PCMs also show excellent thermal cycling stability.

\section{Acknowledgments}

Financial support from the National Science Foundation for Qaidam Saline Lake Chemical Engineering Science of China (No. U1407105) and Natural Science Foundation of Qinghai province of China (No.2015-ZJ-930Q) are gratefully acknowledged.

\section{References}

[1] A.A. Al-Abidi, S.B. Mat, K. Sopian, M.Y. Sulaiman, C.H. Lim, A. Th, Review of thermal energy storage for air conditioning systems, Renew. Sustain. Energy Rev. 2012; 16: 5802-5819.

[2] E. Osterman, V.V. Tyagi, V. Butala, N.A. Rahim, U. Stritih, Review of PCM based cooling technologies for buildings, Energy Build. 2012; 49: 37-49.

[3] V.V. Tyagi, D. Buddhi, R. Kothari, S.K. Tyagi, Phase change material (PCM) based thermal management system for cool energy storage application in building: An experimental study, Energy Build. 2012; 51: 248-254.

[4] Xu B, Li PW, Chan C, Application of phase change materials for thermal energy storage in concentrated solar thermal power plants: A review to recent developments, Applied Energy, 2015; 160:286-307.

[5] Kalbasi, R, Salimpour, MR , Constructal design of horizontal fins to improve the performance of phase change material rectangular enclosures, Appl. Therm. Eng. 2015; 91: 234-244

[6] Xue, HS, Experimental investigation of a domestic solar water heater with solar collector coupled phase-change energy storage, Renew. Energy.2016; 86:257-261.

[7] Xiong WL, Chen Y, Hao M, Zhang L, Mei T, Wang JY, Li JH, Wang XB, Facile synthesis of PEG based shape-stabilized phase change materials and their photo-thermal energy conversion, Appl. Therm. Eng. 2015; 91:630-637.

[8] Feng LL, Wang CY, Song P, Wang HB, Zhang XR, The form-stable phase change materials based on polyethylene glycol and functionalized carbon nanotubes for heat storage, Appl. Therm. Eng. 2015; 90:952-956.

[9] Xu BW, Ma HY, Lu ZY, Li ZJ, Paraffin/expanded vermiculite composite phase 
change material as aggregate for developing lightweight thermal energy storage cement-based composites, Applied Energy, 2015; 160:358-367.

[10] Reddi RSB, Kumar Satuluri VSA, Rai US, Rai RN. Thermal, physicochemical and microstructural studies of binary organic eutectic systems. J Therm Anal Calorim. 2012; 107:377-85.

[11] Zeng JL, Cao Z, Yang DW, Sun LX, Zhang L. Thermal conductivity enhancement of $\mathrm{Ag}$ nanowires on an organic phase change material. J Therm Anal Calorim. 2010; 101:385-9.

[12] N'Tsoukpoe KE, Rammelberg HU , Lele AF, Korhammer K, Watts BA , Schmidt T, Ruck WKL, A review on the use of calcium chloride in applied thermal engineering, Appl. Therm. Eng. 2014; 75:513-531.

[13] Duan ZJ, Zhang HZ, Sun LX, Cao Z, Xu F, Zou YJ, Chu HL, , Qiu SJ, Xiang CL, Zhou HY. $\mathrm{CaCl}_{2} \cdot 6 \mathrm{H}_{2} \mathrm{O} /$ Expanded graphite composite as form-stable phase change materials for thermal energy storage. J Therm Anal Calorim. 2014; 115:111-117.

[14] K. Bilen, F. Takgil, K. Kaygusuz, Thermal energy storage behavior of $\mathrm{CaCl}_{2} \cdot 6 \mathrm{H}_{2} \mathrm{O}$ during melting and solidification, Energy Sources, Part A, 30 (2008) 775-787.

[15] G.A. Lane, Adding strontium chloride or calcium hydroxide to calcium chloride hexahydrate heat storage material, Solar Energy, 1 (1981) 73-75.

[16] J. Paris, R. Jolly, Calcium chloride hexahydrate fusion-solidification behavior, Thermochimica Acta, 2 (1989) 271-278.

[17] D. Liu, Y. L. Xu, Thermoproperties research on nucleators- $\mathrm{CaCl}_{2} \cdot 6 \mathrm{H}_{2} \mathrm{O}$ composites under distinctive systems, Acta Energiae Solaris Sinica, 7 (2007) 732-738. [18] Shin HK, Park M, Kim HY, Park SJ, Thermal property and latent heat energy storage behavior of sodium acetate trihydrate composites containing expanded graphite and carboxymethyl cellulose for phase change materials, Appl. Therm. Eng. 2015; 75:978-983.

[19] W.S. Hummers, R.E. Offeman, Preparation of Graphitic Oxide .J. Am. Chem. Soc. 1958; 80:1339-1339.

[20] S.Y. Lee, H.K. Shin, M. Park, K.Y. Rhee, S.J. Park, Thermal characterization of erythritol/expanded graphite composites for high thermal storage capacity, Carbon 2014; 68:67-72. 
Table 1

The compositions of the $\mathrm{CaCl}_{2} \cdot 6 \mathrm{H}_{2} \mathrm{O}$ composites containing $\mathrm{SrCl}_{2} \cdot 6 \mathrm{H}_{2} \mathrm{O}$ and EGO.

\begin{tabular}{cccc}
\hline samples & $\mathrm{SrCl}_{2} \cdot 6 \mathrm{H}_{2} \mathrm{O}$ and EGO contents in the $\mathrm{CaCl}_{2} \cdot 6 \mathrm{H}_{2} \mathrm{O}$ composites \\
\cline { 2 - 4 } & $\begin{array}{c}\mathrm{EGO} \\
(\text { wt } \%)\end{array}$ & $\begin{array}{c}\mathrm{SrCl}_{2} \cdot 6 \mathrm{H}_{2} \mathrm{O} \\
(\text { wt } \%)\end{array}$ & $\begin{array}{c}\text { SDBS } \\
(\text { wt } \%)\end{array}$ \\
\hline $\mathrm{N}_{0}$ & 0 & 0 & 0 \\
\hline $\mathrm{N}_{1}$ & 0 & 1 & 0 \\
\hline $\mathrm{N}_{2}$ & 0 & 2 & 0 \\
\hline $\mathrm{N}_{3}$ & 0 & 3 & 0 \\
\hline $\mathrm{N}_{4}$ & 0 & 4 & 0 \\
\hline $\mathrm{N}_{5}$ & 0 & 5 & 0 \\
\hline $\mathrm{N}_{3-2}$ & 0.2 & 3 & 1 \\
\hline $\mathrm{N}_{3-4}$ & 0.4 & 3 & 1 \\
\hline $\mathrm{N}_{3-6}$ & 0.6 & 3 & 1 \\
\hline $\mathrm{N}_{3-8}$ & 0.8 & 3 & 1 \\
\hline $\mathrm{N}_{3-10}$ & 1.0 & 3 & \\
\hline $\mathrm{N}_{3-12}$ & 1.2 & 3 & 1 \\
\hline
\end{tabular}




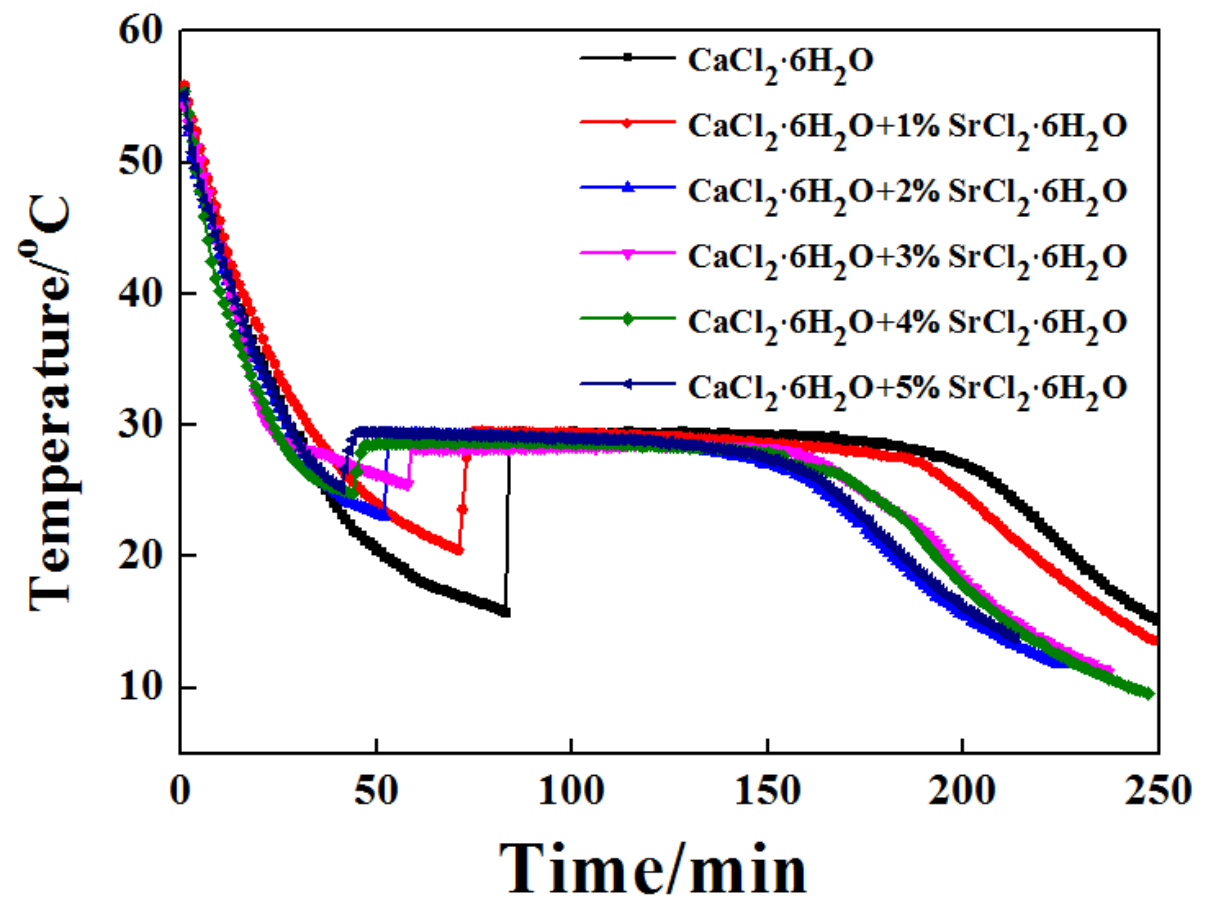

Fig.1 Influence of the concentration of $\mathrm{SrCl}_{2} \cdot 6 \mathrm{H}_{2} \mathrm{O}$ on the supercooling degree of $\mathrm{CaCl}_{2} \cdot 6 \mathrm{H}_{2} \mathrm{O}$ PCM.

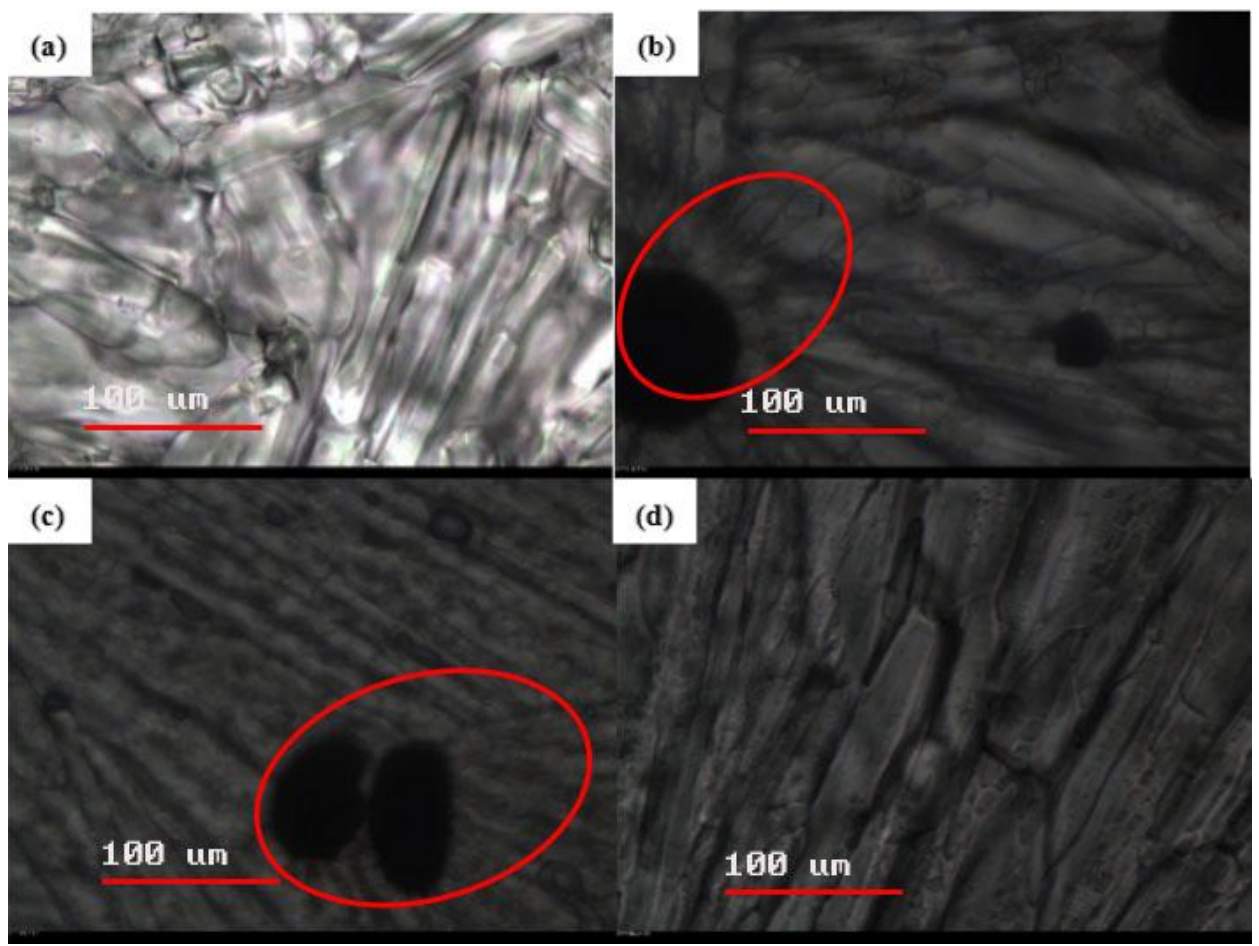

Fig. 2. Optical microscopy images of pure $\mathrm{CaCl}_{2} \cdot 6 \mathrm{H}_{2} \mathrm{O}$ (a) and the $\mathrm{CaCl}_{2} \cdot 6 \mathrm{H}_{2} \mathrm{O}$ containing $3.0 \mathrm{wt} \% \mathrm{SrCl}_{2} \cdot 6 \mathrm{H}_{2} \mathrm{O}$ (b, c, d) (magnification: $200 \times$ ) 


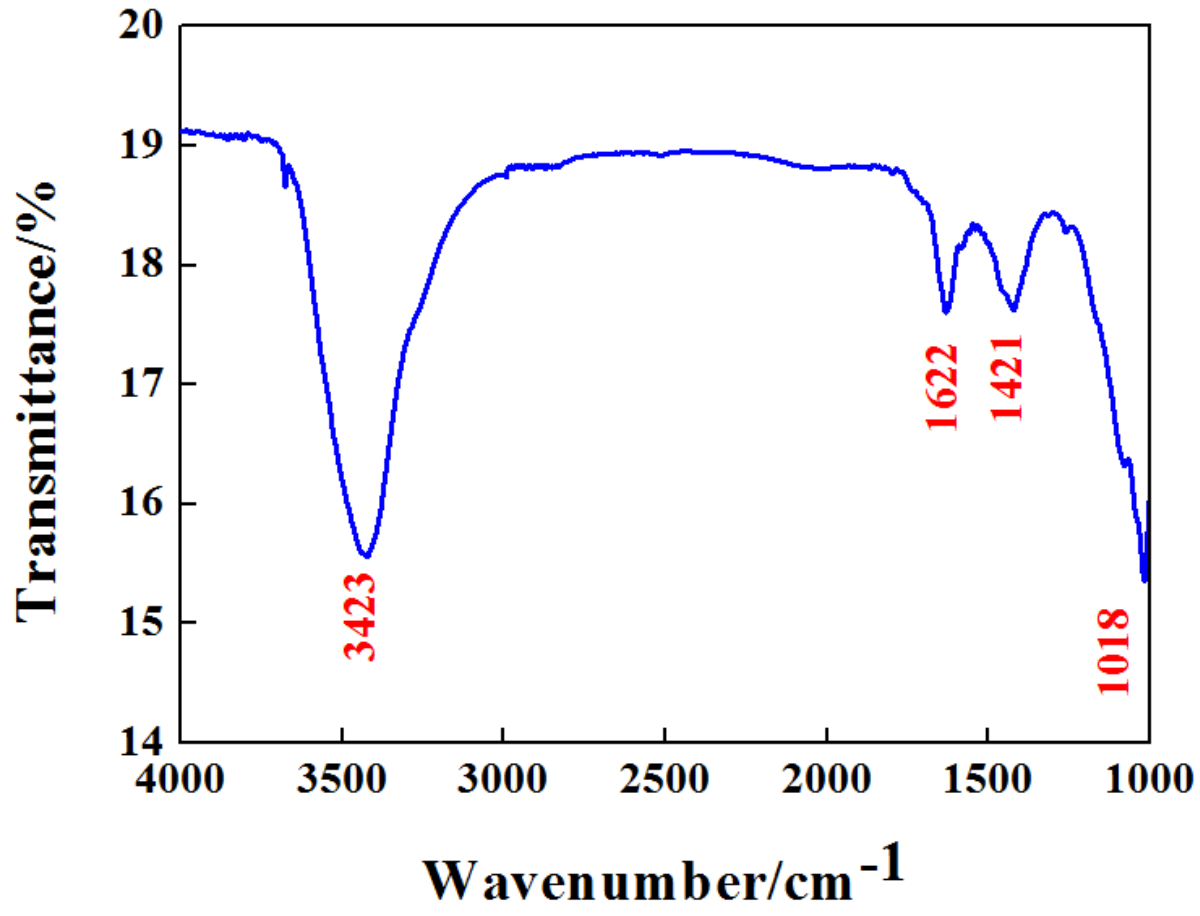

Fig.3 The FTIR spectra of EGO.

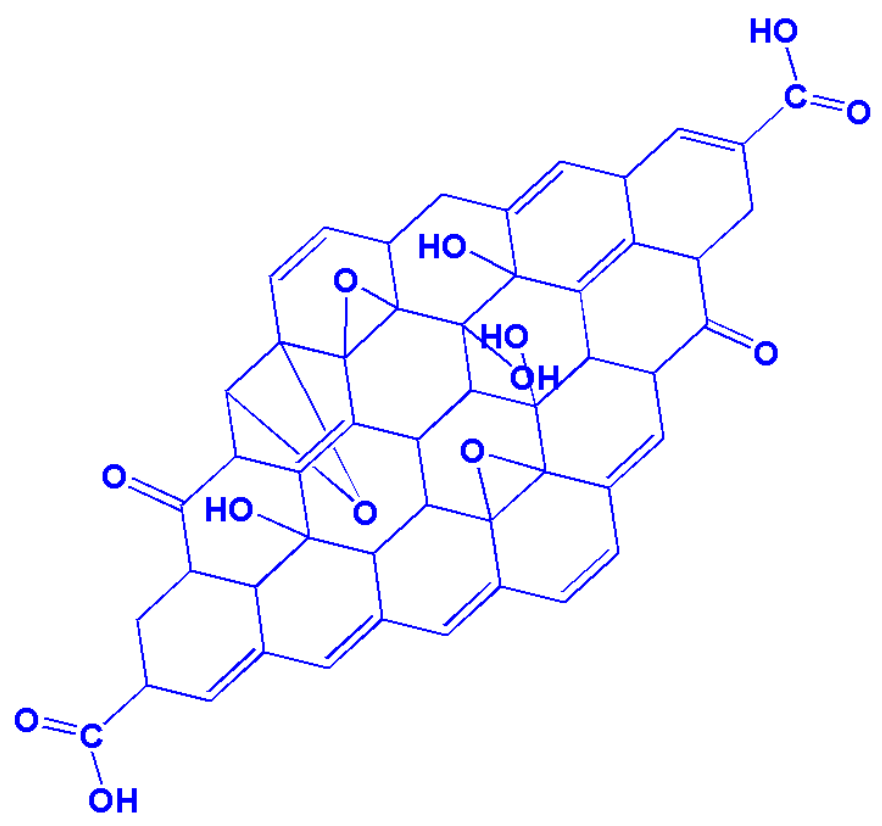

Fig. 4 Diagram of oxidized expanded graphite layers. 


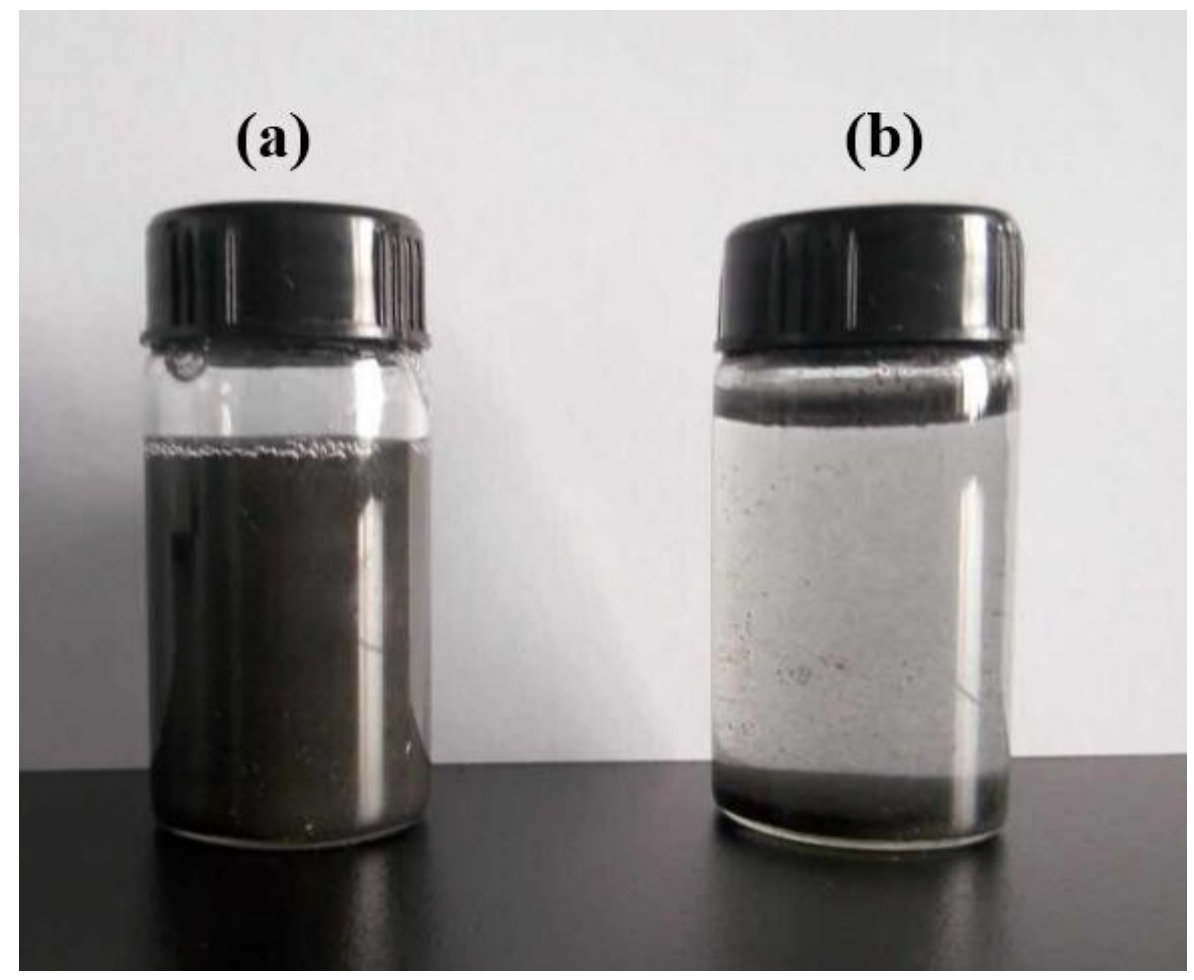

Fig. 5 Digital photos showing dispersion stability in water of (a) EG for $1 \mathrm{~h}$ and (b) EGO for $48 \mathrm{~h}$.

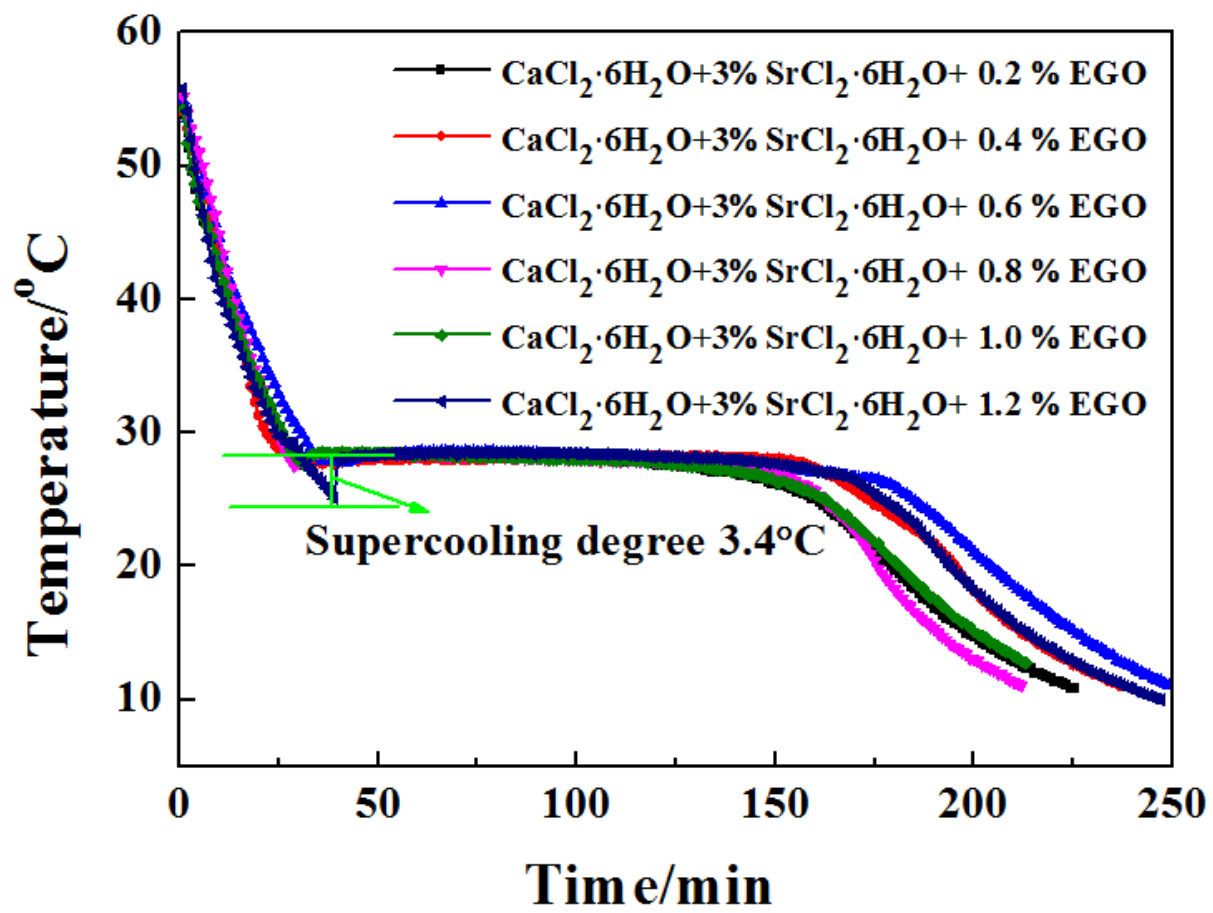

Fig. 6 Cooling curves of $\mathrm{CaCl}_{2} \cdot 6 \mathrm{H}_{2} \mathrm{O} / \mathrm{SrCl}_{2} \cdot 6 \mathrm{H}_{2} \mathrm{O} / \mathrm{EGO} /$ composites $\left(\mathrm{N}_{3-2}, \mathrm{~N}_{3-4}, \mathrm{~N}_{3-6}\right.$, $\mathrm{N}_{3-8}, \mathrm{~N}_{3-10}, \mathrm{~N}_{3-12}$ ). 


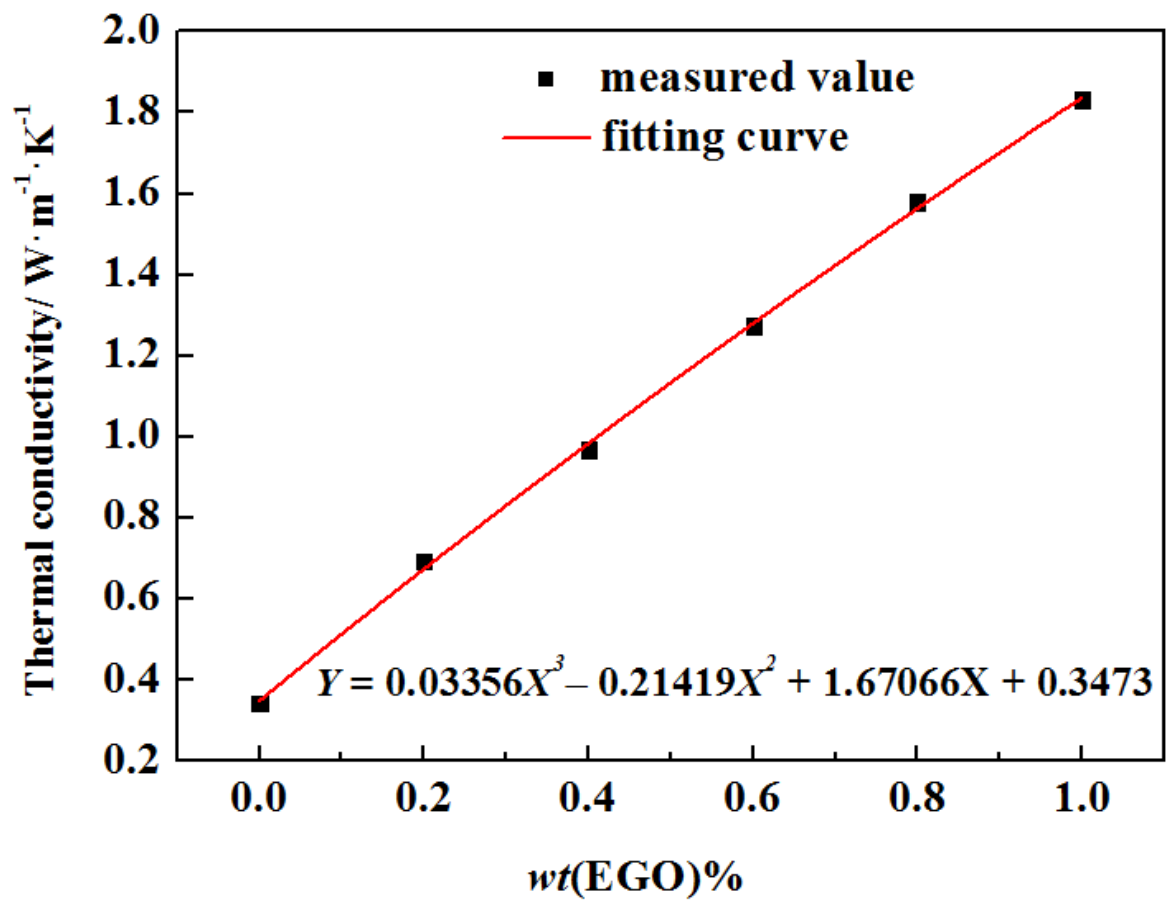

Fig. 7 Effects of EGO on the thermal conductivity of $\mathrm{CaCl}_{2} \cdot 6 \mathrm{H}_{2} \mathrm{O} / \mathrm{SrCl}_{2} \cdot 6 \mathrm{H}_{2} \mathrm{O} / \mathrm{EGO} /$ composites $\left(\mathrm{N}_{3}, \mathrm{~N}_{3-2}, \mathrm{~N}_{3-4}, \mathrm{~N}_{3-6}, \mathrm{~N}_{3-8}, \mathrm{~N}_{3-10}\right)$.

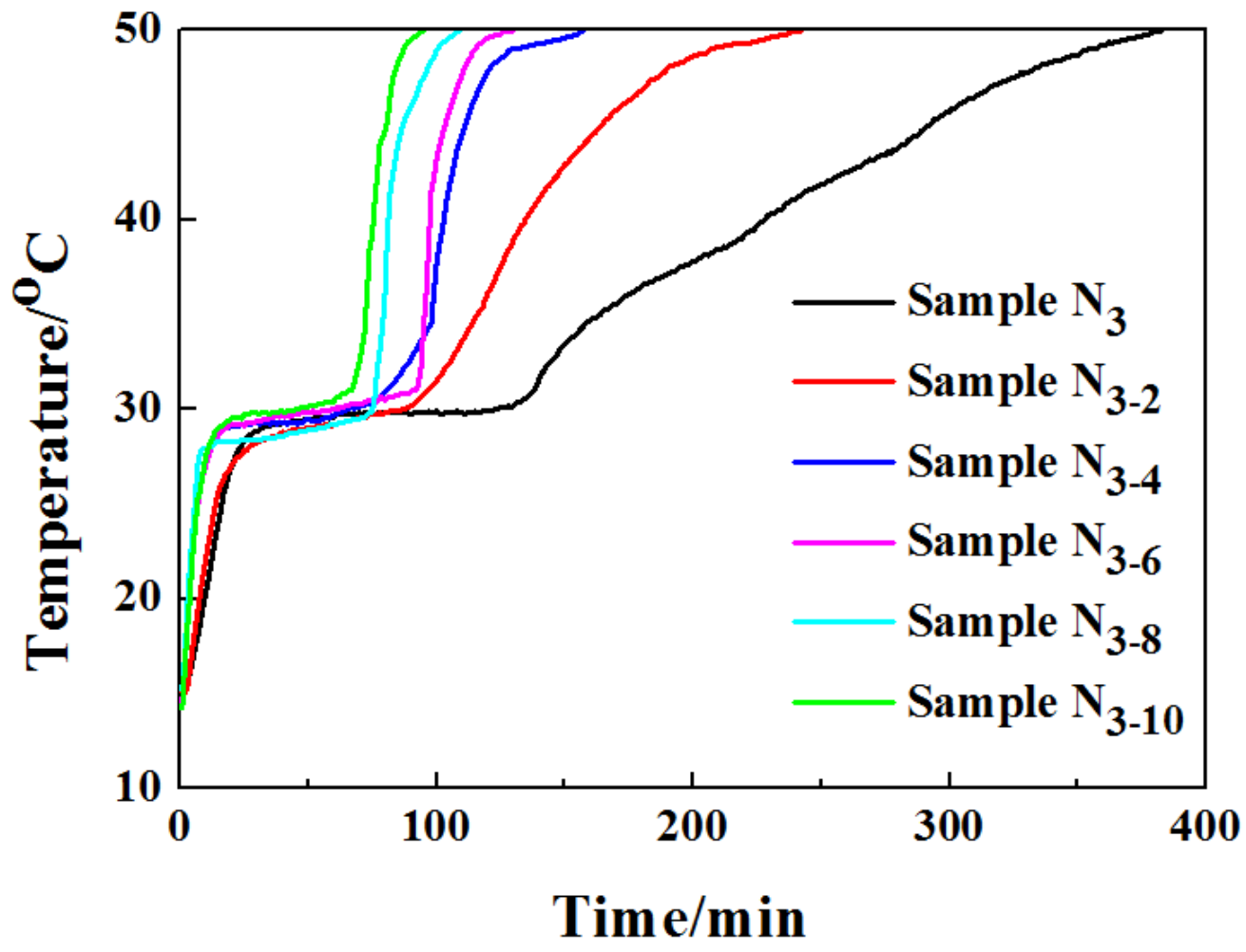

Fig. 8 Heat storage curves of $\mathrm{CaCl}_{2} \cdot 6 \mathrm{H}_{2} \mathrm{O} / \mathrm{SrCl}_{2} \cdot 6 \mathrm{H}_{2} \mathrm{O} / \mathrm{EGO} /$ composites PCMs. 


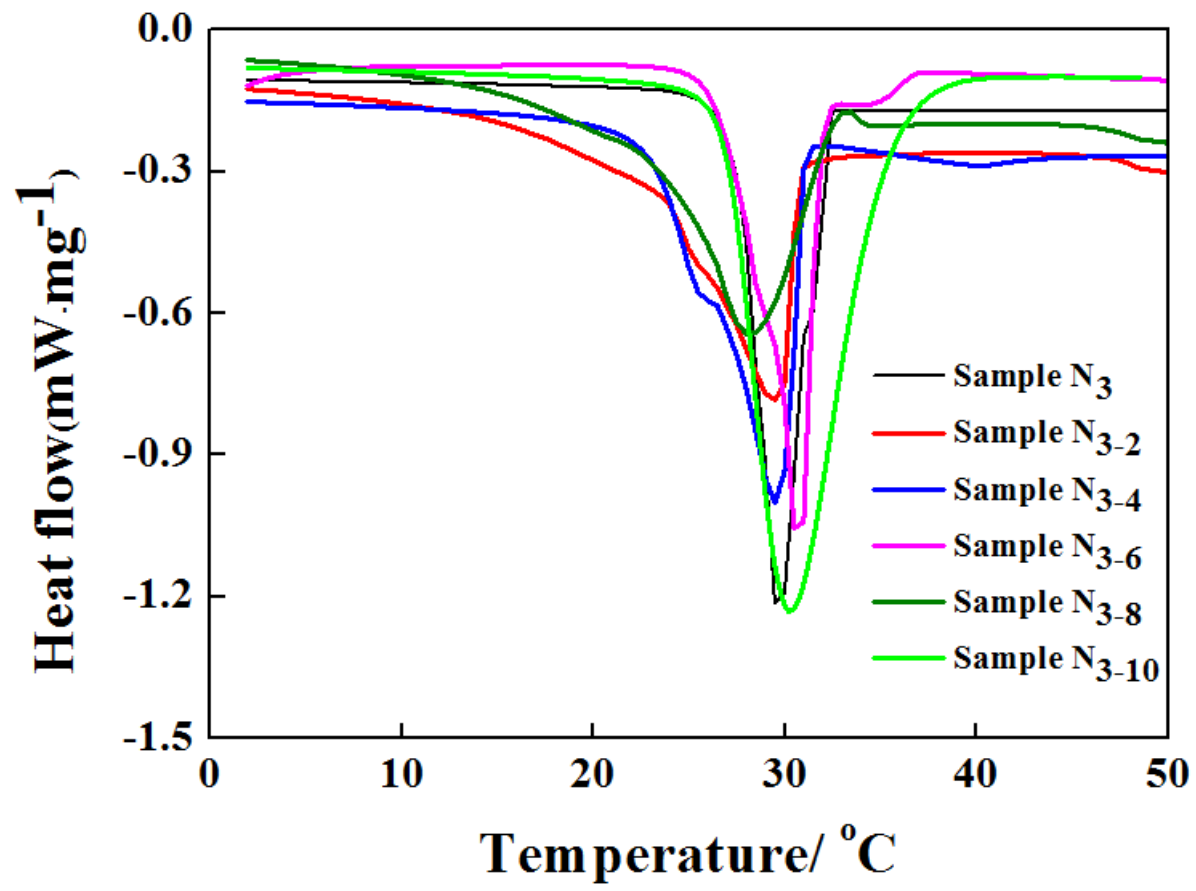

Fig. 9 DSC Melting curves of $\mathrm{CaCl}_{2} \cdot 6 \mathrm{H}_{2} \mathrm{O} / \mathrm{SrCl}_{2} \cdot 6 \mathrm{H}_{2} \mathrm{O} / \mathrm{EGO} /$ composites PCMs.

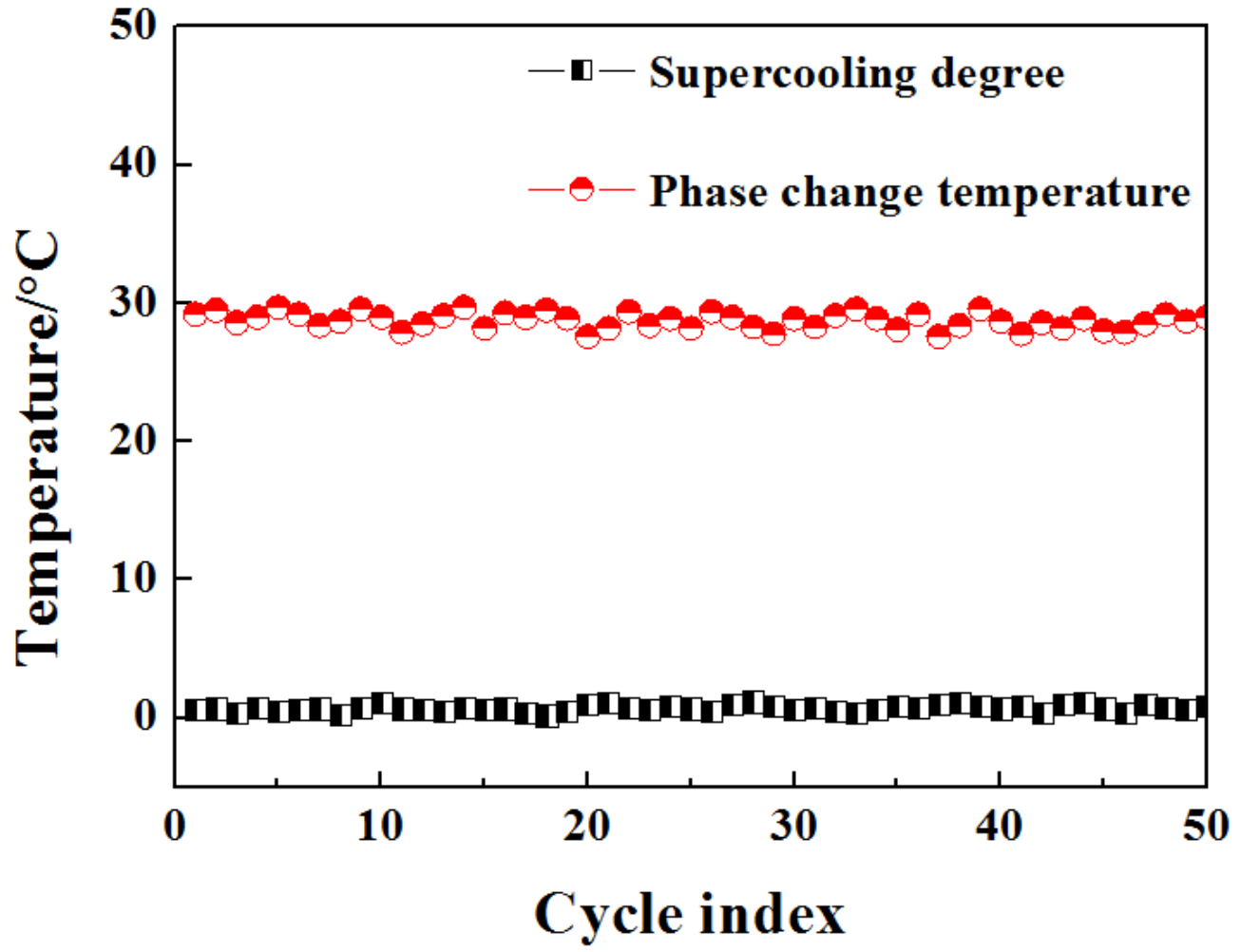

Fig.10 Results of cyclic performance tests of the $\mathrm{CaCl}_{2} \cdot 6 \mathrm{H}_{2} \mathrm{O} / \mathrm{SrCl}_{2} \cdot 6 \mathrm{H}_{2} \mathrm{O} / \mathrm{EGO} /$ composites PCMs $\left(\mathrm{N}_{3-8}\right)$. 


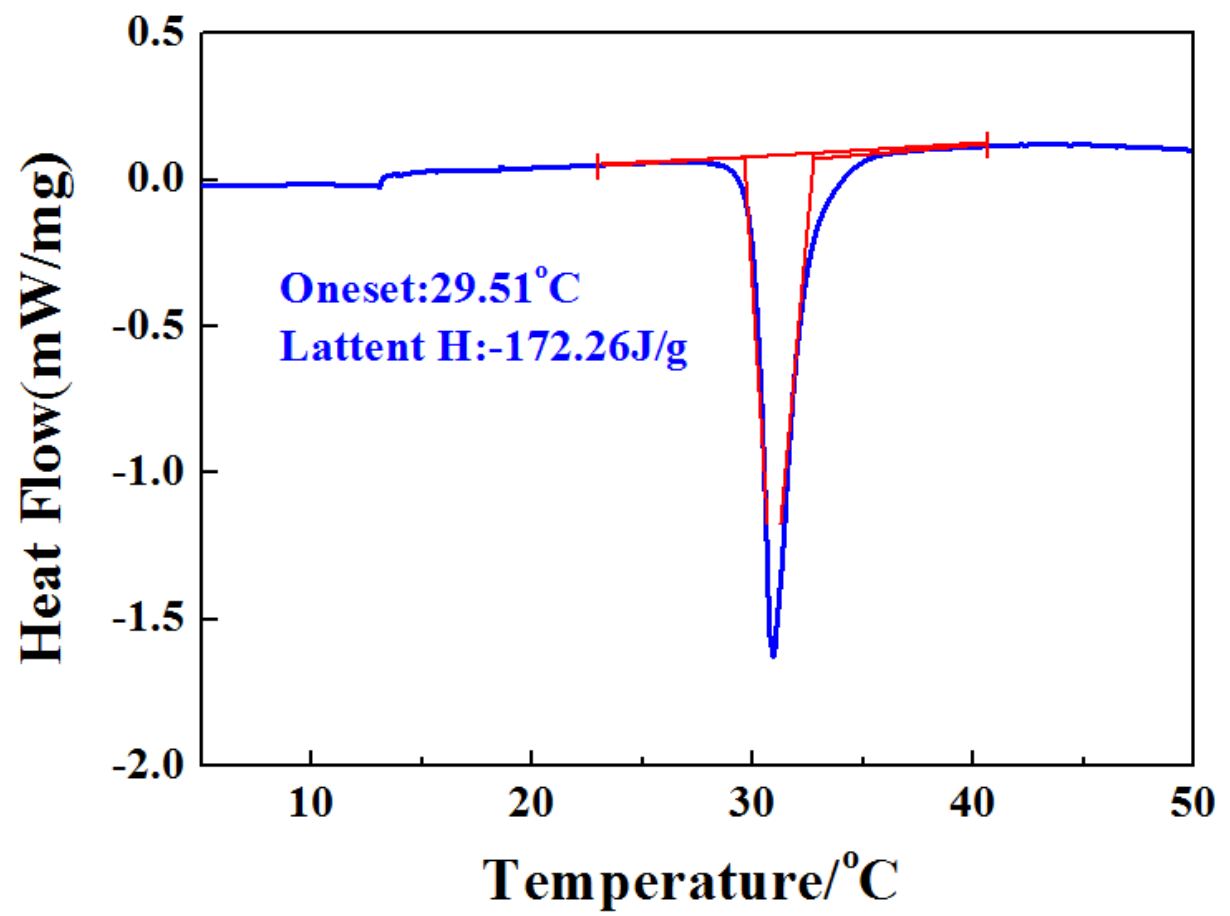

Fig.11 DSC Melting curve of the $\mathrm{CaCl}_{2} \cdot 6 \mathrm{H}_{2} \mathrm{O} / \mathrm{SrCl}_{2} \cdot 6 \mathrm{H}_{2} \mathrm{O} / \mathrm{EGO} /$ composites PCMs $\left(\mathrm{N}_{3-10}\right)$ (after 50 melting-freezing cycles).

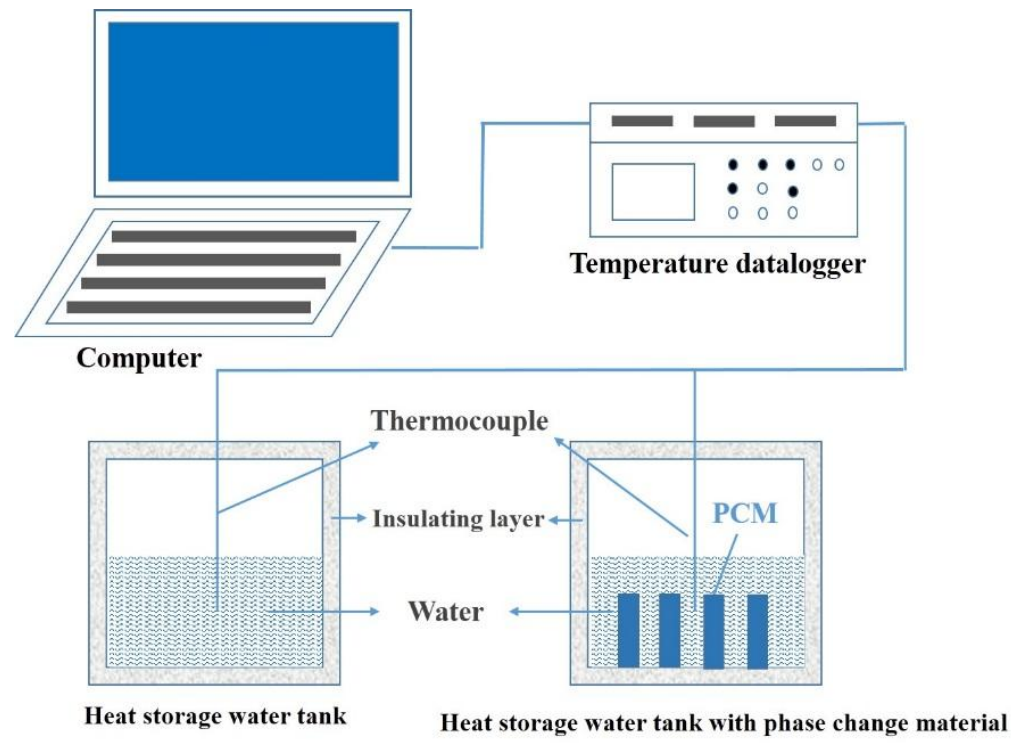

Fig. 12 Schematic diagram for simulation experiments. 


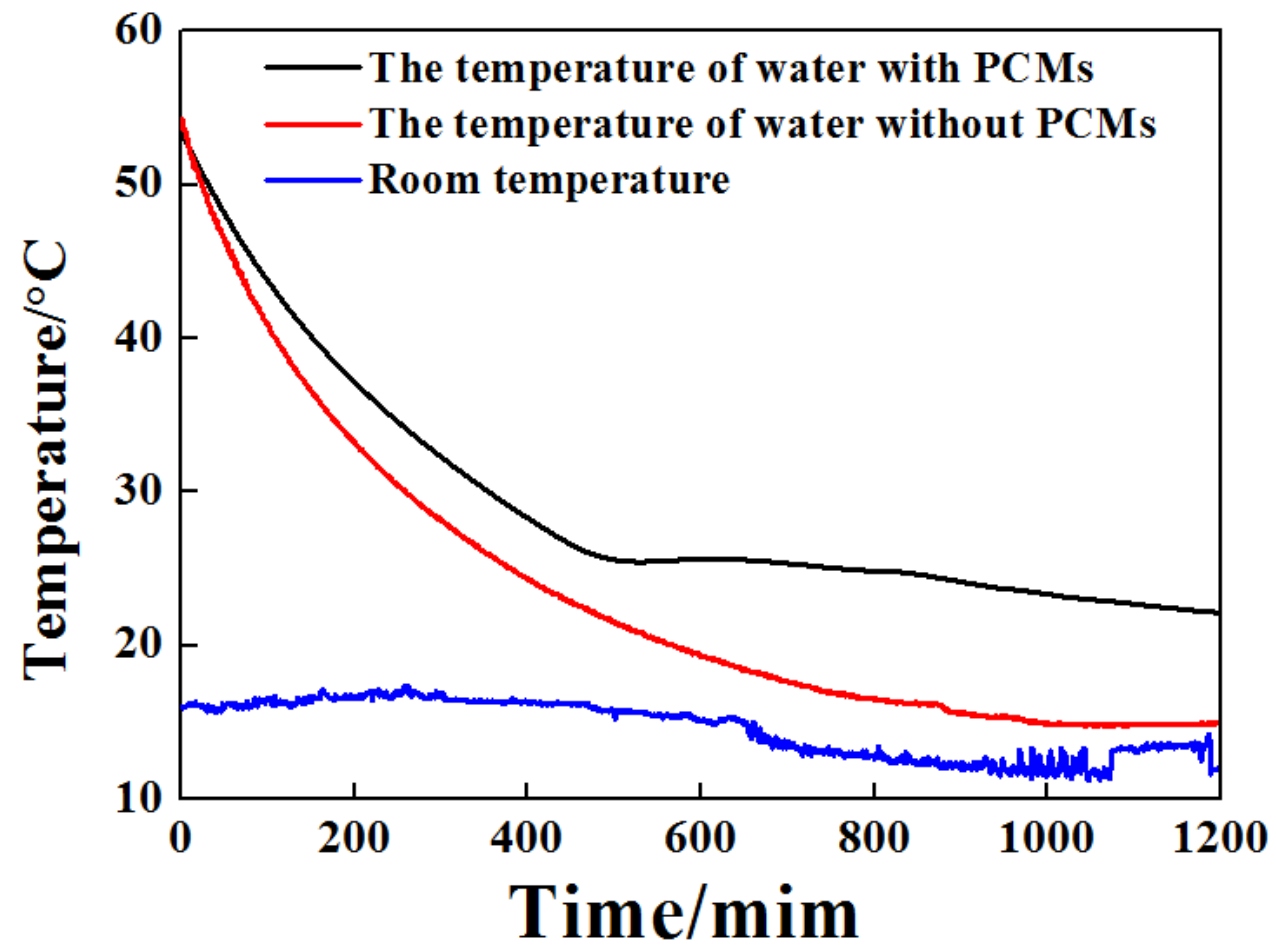

Fig.13 The temperature change of water in the heat storage tank. 